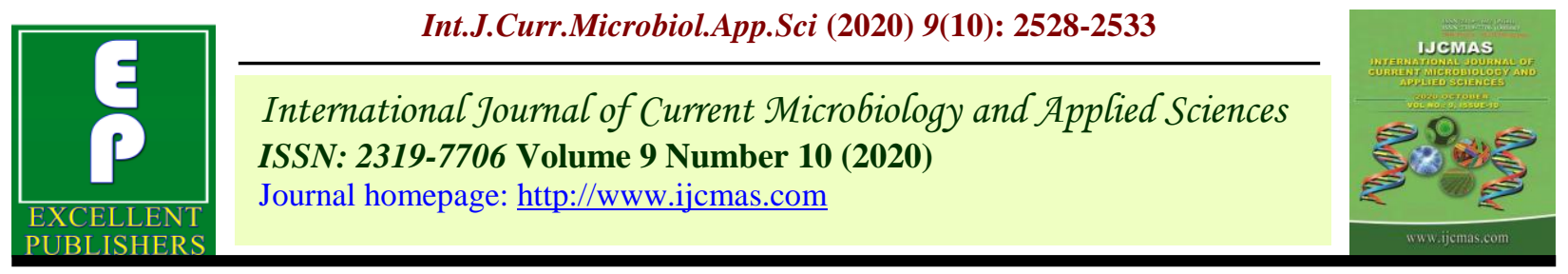

Original Research Article

https://doi.org/10.20546/ijcmas.2020.910.304

\title{
Effect of Nitrogen, Potassium and Zinc Nanofertilizer on Growth, Yield and Quality of Phalsa (Grewia subinaequalis)
}

\author{
Bini Marina James* and V.M. Prasad \\ Department of Horticulture, Sam Higginbottom University of Agriculture, Technology and \\ Sciences, Prayagraj-211007, India \\ *Corresponding author
}

\section{A B S T R A C T}

\begin{tabular}{|l|}
\hline Ke y w o r d s \\
Phalsa, Nutrients, \\
Growth, \\
Nanofertilizer, \\
Yield \\
\hline Article Info \\
\hline $\begin{array}{l}\text { Accepted: } \\
\text { 20 September } 2020 \\
\text { Available Online: } \\
\text { 10 October } 2020\end{array}$ \\
\hline
\end{tabular}

A study was made on the application of Nitrogen, Potassium and Zinc Nanofertilizer on Phalsa (Grewia Subinaequalis) in order to check its effect on growth, yield and quality of the fruit. The present study was carried out during January 2019 to June 2019 in Central horticulture research farm of Department of Horticulture, SHUATS, Prayagraj. The study was conducted in Randomized Block Design with 11 treatments replicated thrice. The treatments were $\mathrm{T}_{0}(\mathrm{Control}), \mathrm{T}_{1}\left[\mathrm{~N} 50 \mathrm{~g}+\mathrm{K} 20 \mathrm{~g}\right.$ (50\% of the RDF)], $\mathrm{T}_{2}[\mathrm{~N} 100 \mathrm{~g}+\mathrm{K} 40 \mathrm{~g}$ (100\% of the RDF)], $\mathrm{T}_{3}$ (N 50g + K 20g + Zn 0.2\%), $\mathrm{T}_{4}$ (N 50g $\left.+\mathrm{K} 20 \mathrm{~g}+\mathrm{Zn} 0.4 \%\right), \mathrm{T}_{5}(\mathrm{~N}$ $50 \mathrm{~g}+\mathrm{K} 20 \mathrm{~g}+\mathrm{Zn} 0.2 \%), \mathrm{T}_{6}\left(\mathrm{~N} 50 \mathrm{~g}+\mathrm{K} 40 \mathrm{~g}+\mathrm{Zn} \mathrm{0.4 \% ),} \mathrm{T}_{7}(\mathrm{~N} 100 \mathrm{~g}+\mathrm{K} \mathrm{20g}+\mathrm{Zn} 0.2 \%)\right.$, $\mathrm{T}_{8}\left(\mathrm{~N} \mathrm{100g}+\mathrm{K} 40 \mathrm{~g}+\mathrm{Zn} \mathrm{0.4 \% ),} \mathrm{T}_{9}(\mathrm{~N} \mathrm{100g}+\mathrm{K} 40 \mathrm{~g}+\mathrm{Zn} 0.2 \%), \mathrm{T}_{10}(\mathrm{~N} \mathrm{100g}+\mathrm{K} 40 \mathrm{~g}+\right.$ Zn $0.4 \%$ ) Among all the above treatments, plants which were augmented according to treatment $\mathrm{T}_{6}(\mathrm{~N} 50 \mathrm{~g}+\mathrm{K} 40 \mathrm{~g}+\mathrm{Zn} 0.4 \%$ ) showed significantly superior results in the plant height whereas Treatment $\mathrm{T}_{10}(\mathrm{~N} 100 \mathrm{~g}+\mathrm{K} 40 \mathrm{~g}+\mathrm{Zn} \mathrm{0.4 \% )} \mathrm{showed} \mathrm{significant} \mathrm{superior}$ result in terms of plant spread, number of shoots, Number of flowering nodes, average number of fruits per bush, Fruit yield $(\mathrm{kg})$ per bush, Titratable acidity, TSS and Ascorbic acid content over the treatment $\mathrm{T}_{0}(\mathrm{Control})$.

\section{Introduction}

Phalsa (Grewia subinaequalis) is also known as star apple. It is a deciduous, subtropical fruit which is aborigine to Indian subcontinent and south East Asia. The fruit botanically is a drupe. It belongs to the flowering member of Tiliaceae with chromosome number $2 n=36$ (Tripathi, 2009). The family Tiliaceae is shrubs, trees, or rarely herbs comprising about 40 genera and 450 species. It is considered to be one of the major underutilized fruit crops which grow well in arid and semi-arid zones. The plant grown in northern India is generally subjected to annual pruning which is considered to be as major intercultural operation that helps in the emergence of new shoots whereas in some southern states it is kept evergreen. It is hardy crop that grows well in marginal soil and can withstand temperatures $3^{\circ} \mathrm{C}$ to $45^{\circ} \mathrm{C}$. The bush comprises of long slender droopy branches with simple alternate leaves (Tripathi, 2009). The flowers are generally yellow to orange in colour that bears in the months of MarchApril. The fruits are round in shape, colour ranging from dark purple to crimson red in colour that bears in the month of April to June. Ripe fruits contain 50-60\% juice, 10$11 \%$ sugars and 2-2.5\% acid (Singh and Singh 2017). The fruit cultivation is 
commercially accepted by very few northern and western states of India such as Punjab, Uttar Pradesh, Madhya Pradesh and Rajasthan whereas in some states it is grown in small scale such as Maharashtra, Gujarat, Andhra Pradesh, Bihar and West Bengal. The current statistic of areas and production of the fruit is unknown except the state Punjab.

In the modern world were very few crops are grown as industrial or commercial crops whether it is cereals, pulses, vegetable and fruits crops for their staple dietary wants of humans. The underutilized fruit crops are equally favorable for their potential dietary diverseness and other health benefits including high antioxidant value, vitamins and minerals etc. which are helpful to surmount many direct and indirect problems such as malnutrition, carbon emission etc.

Plant nutrition is the vital aspect to overall plant growth and production. Nitrogen $(\mathrm{N})$ is the most important nutrient for its presence in the structure if protein molecule and role in the photosynthesis, potassium $(\mathrm{K})$ is essential for the enzyme activation and both effecting the cell division and enlargement Kumar et al., (2014). Nanotechnology research is one of the major emerging areas of research with its application in science and technology for the purpose of manufacturing new materials at nano-scale level (Albrecht et al., 2006).It is the study of basic principles for molecules and compounds measuring no more than 100 nanometers (Reynolds, 2002). Zinc ( $\mathrm{Zn}$ ) is a heavy metal that regulates enzyme activities in plants. The use of $\mathrm{Zn}$ in the form of nanofertilizer has shown many significant study evidences such as increase in the plant growth and development (Kumar et al., 2017) in strawberry, (Al-Juthery and Saadoun 2018) in Jerusalem artichoke and (Hak El-Said et $a l ., 2019)$ in flame seedless Grape, increased growth in seedlings, number of fruits and height of the plant (Gracia-lopez et al., 2019) in Habanero chili pepper plants.

\section{Materials and Methods}

The present study was conducted in Randomized Block Design with 11 treatments replicated thrice. The treatments were $\mathrm{T}_{0}$ Control (Irrigation only), $\mathrm{T}_{1}(\mathrm{~N} 50 \mathrm{~g}+\mathrm{K} 20 \mathrm{~g}$ (50\% of the RDF)), $\mathrm{T}_{2}(\mathrm{~N} 100 \mathrm{~g}+\mathrm{K} 40 \mathrm{~g}$ $(100 \%$ of the RDF) $), \mathrm{T}_{3}(\mathrm{~N} 50 \mathrm{~g}+\mathrm{K} 20 \mathrm{~g}+\mathrm{Zn}$ $0.2 \%), \mathrm{T}_{4}(\mathrm{~N} 50 \mathrm{~g}+\mathrm{K} 20 \mathrm{~g}+\mathrm{Zn} 0.4 \%), \mathrm{T}_{5}(\mathrm{~N}$ $50 \mathrm{~g}+\mathrm{K} 40 \mathrm{~g}+\mathrm{Zn} 0.2 \%), \mathrm{T}_{6}(\mathrm{~N} 50 \mathrm{~g}+\mathrm{K} 40 \mathrm{~g}+$ Zn $0.4 \%), \mathrm{T}_{7}(\mathrm{~N} 100 \mathrm{~g}+\mathrm{K} 20 \mathrm{~g}+\mathrm{Zn} 0.2 \%)$, $\mathrm{T}_{8}(\mathrm{~N} 100 \mathrm{~g}+\mathrm{K} 40 \mathrm{~g}+\mathrm{Zn} 0.4 \%), \mathrm{T}_{9}(\mathrm{~N} 100 \mathrm{~g}+$ $\mathrm{K} 40 \mathrm{~g}+\mathrm{Zn} 0.2 \%), \mathrm{T}_{10}(\mathrm{~N} 100 \mathrm{~g}+\mathrm{K} 40 \mathrm{~g}+\mathrm{Zn}$ $0.4 \%$ ) where nitrogen and potassium were given through Urea and MOP (Murate of Potash). Zinc was applied through nano chelated Zinc liquid nanofertilizer applied through foliar application and these were applied in combination of total two split doze before and after flowering.

\section{Climatic condition in the experimental site}

The district Prayagraj of south east, Uttar Pradesh comes under the subtropical belt of Indian climatic zones. This place is situated at 25024'23" N latitude, 81050'38' E longitude at the altitude of 98 meter above the sea level (MSL) which experiences extremely hot summer and fairly cold winter. The maximum temperature of the location reaches up to $46^{\circ}$ $\mathrm{C}$ to $48^{\circ} \mathrm{C}$ and seldom falls as low as $4^{\circ} \mathrm{C}$ to $5^{\circ} \mathrm{C}$. The relative humidity ranges between 20 to $94 \%$. The average rainfall in this area is around $1013.4 \mathrm{~mm}$ annually. However, occasional precipitation is also not uncommon during winter months.

\section{Results and Discussions}

The effect of result of the experiment entitled "Effect of Nitrogen, potassium and Zinc Nanofertilizer on the growth, yield and quality of Phalsa (Grewia subinaequalis)" was carried out during January to June in the, Department of Horticulture, Sam Higginbottom University of Agriculture, Technology \& Sciences, Prayagraj. 
Table.1 Effect of different treatments on the Plant height, Plant spread, Number of shoots per bush of Phalsa (Grewia subinaequalis)

\begin{tabular}{|c|c|c|c|c|c|c|c|c|c|c|c|c|c|}
\hline \multirow[t]{2}{*}{ S.no } & \multirow[t]{2}{*}{ Treatments } & \multicolumn{4}{|c|}{ Plant height } & \multicolumn{4}{|c|}{ Plant spread } & \multicolumn{4}{|c|}{ Number of shoots per bush } \\
\hline & & $\begin{array}{c}60 \\
\text { DAP }\end{array}$ & $\begin{array}{c}80 \\
\text { DAP }\end{array}$ & $\begin{array}{c}100 \\
\text { DAP }\end{array}$ & $\begin{array}{c}120 \\
\text { DAP }\end{array}$ & $\begin{array}{c}60 \\
\text { DAP }\end{array}$ & $\begin{array}{c}80 \\
\text { DAP }\end{array}$ & $\begin{array}{c}100 \\
\text { DAP }\end{array}$ & $\begin{array}{c}120 \\
\text { DAP }\end{array}$ & $\begin{array}{c}\text { 60 } \\
\text { DAP }\end{array}$ & $\begin{array}{c}\mathbf{8 0} \\
\text { DAP }\end{array}$ & $\begin{array}{c}100 \\
\text { DAP }\end{array}$ & $\begin{array}{c}120 \\
\text { DAP }\end{array}$ \\
\hline 1. & $\mathbf{T}_{\mathbf{0}}$ & 31.57 & 41.2 & 53.9 & 70.2 & 48.67 & 52.8 & 84.57 & 84.57 & 31.33 & 40 & 45 & 50 \\
\hline 2. & $\mathbf{T}_{1}$ & 40.77 & 55.13 & 62.07 & 78.27 & 57.2 & 64.2 & 87.03 & 94.80 & 36 & 43 & 54 & 58.33 \\
\hline 3. & $\mathbf{T}_{2}$ & 46.80 & 60.3 & 72.93 & 82.87 & 65.83 & 66 & 91.80 & 96.50 & 39.33 & 48 & 54 & 61 \\
\hline 4. & $\mathbf{T}_{\mathbf{3}}$ & 49.77 & 61.4 & 77.3 & 84.93 & 63.13 & 72.63 & 90.60 & 95.23 & 40.67 & 55.33 & 63.67 & 69 \\
\hline 5. & $\mathbf{T}_{4}$ & 41.87 & 67.67 & 84.13 & 93.27 & 62.27 & 72.03 & 94.37 & 100.73 & 42.67 & 52.33 & 60 & 63.67 \\
\hline 6. & $\mathbf{T}_{5}$ & 50.87 & 65.23 & 86.77 & 97.63 & 61.77 & 69.23 & 98.27 & 102.57 & 48 & 57.67 & 66 & 70 \\
\hline 7. & $\mathbf{T}_{6}$ & 62.17 & 80.3 & 99.97 & 114.07 & 65.13 & 83.93 & 84.63 & 94.87 & 51.67 & 64 & 75.67 & 79.33 \\
\hline 8. & $\mathbf{T}_{7}$ & 51.87 & 69.17 & 92 & 97.37 & 66.67 & 74.63 & 92.47 & 96.77 & 41.67 & 55.67 & 70 & 73.33 \\
\hline 9. & $\mathbf{T}_{8}$ & 53.83 & 64.57 & 91.37 & 103.07 & 65.17 & 72.87 & 90.67 & 96.60 & 47 & 58.33 & 79.67 & 70 \\
\hline 10. & $\mathbf{T}_{9}$ & 52.63 & 68.4 & 91.53 & 100.13 & 68.4 & 76.4 & 85.33 & 99.13 & 52 & 60.67 & 69.33 & 73 \\
\hline 11. & $\mathbf{T}_{10}$ & 60.87 & 80.13 & 96.73 & 107.7 & 67 & 86.70 & 98.50 & 104.87 & 61.67 & 69.67 & 79.67 & 84 \\
\hline & $\mathrm{SE}(\mathrm{d})$ & 2.1 & 1.13 & 1.68 & 1.57 & 8.02 & 1.65 & 6.32 & 3.20 & 1.63 & 1.64 & 1.3 & 1.25 \\
\hline & C.D at $5 \%$ & 4.38 & 3.38 & 4.99 & 4.68 & 2.7 & 4.91 & 3.03 & 6.68 & 4.87 & 4.89 & 3.87 & 3.72 \\
\hline
\end{tabular}


Table.2 Effect of different treatments on Days taken from pruning to flowering, number of flowering nodes per bush, days taken from pruning to fruit set, average number of fruits per bush, fruit yield $(\mathrm{kg})$ per bush, T.S.S, Titratable acidity, Ascorbic acid content

\begin{tabular}{|c|c|c|c|c|c|c|c|}
\hline S.No. & Treatments & $\begin{array}{c}\text { Number of } \\
\text { flowering } \\
\text { nodes }\end{array}$ & $\begin{array}{l}\text { Average } \\
\text { number of } \\
\text { fruits per } \\
\text { bush }\end{array}$ & $\begin{array}{c}\text { Fruit } \\
\text { yield } \\
\text { (kg)per } \\
\text { bush }\end{array}$ & $\begin{array}{l}\text { T.S.S } \\
\left({ }^{\circ} \text { Brix }\right)\end{array}$ & $\begin{array}{c}\text { Titratable } \\
\text { acidity }\end{array}$ & $\begin{array}{l}\text { Ascorbic } \\
\text { acid } \\
\text { content }\end{array}$ \\
\hline 1. & $\mathbf{T}_{\mathbf{0}}$ & 8.33 & 999.66 & 1.19 & 18 & 2.96 & 28.61 \\
\hline 2. & $T_{1}$ & 11.67 & 1282.33 & 1.64 & 19.6 & 2.94 & 30.7 \\
\hline 3. & $\mathbf{T}_{2}$ & 13.33 & 1776 & 1.89 & 20 & 2.96 & 28.84 \\
\hline 4. & $\mathbf{T}_{3}$ & 17.33 & 2529 & 2.33 & 19.6 & 2.45 & 35.38 \\
\hline 5. & $\mathbf{T}_{4}$ & 18.33 & 2162.33 & 2.81 & 20 & 2.13 & 35.9 \\
\hline 6. & $T_{5}$ & 20.67 & 2488.67 & 2.36 & 22.8 & 2.27 & 34.82 \\
\hline 7. & $\mathbf{T}_{6}$ & 22.33 & 3885.33 & 3.54 & 22 & 2.24 & 38.48 \\
\hline 8. & $\mathbf{T}_{7}$ & 20.33 & 3819.67 & 2.95 & 20.33 & 2.83 & 34.33 \\
\hline 9. & $\mathbf{T}_{8}$ & 20.33 & 3188 & 2.77 & 20.5 & 2.69 & 35.67 \\
\hline 10. & $\mathbf{T}_{\mathbf{9}}$ & 19.33 & 3288 & 3.12 & 21.33 & 2.14 & 34.49 \\
\hline 11. & $T_{10}$ & 23.33 & 4580.33 & 3.95 & 24 & 1.98 & 39.45 \\
\hline & S.E(d) & 1.39 & 357.04 & 0.24 & 0.89 & 0.08 & 2.86 \\
\hline \multicolumn{2}{|c|}{ C.D at $5 \%$} & 2.90 & 750 & 0.50 & 1.87 & 0.25 & 5.97 \\
\hline
\end{tabular}


The significant effect on the plant attributes may be due to the ample nutrient supplied through the combination of Nitrogen, Potassium and Zinc liquid nanofertilizer which certainly effected the rate of photosynthesis, metabolic activities, cell multiplication and elongation, and pollen fertility etc. The growth attributes such as maximum plant height (114.06) was recorded with the treatment combination of $\mathrm{T}_{6}(\mathrm{~N} 50 \mathrm{~g}+$ $\mathrm{K} 40 \mathrm{~g}+\mathrm{Zn} \mathrm{0.4 \% )}$ which was found to be superior over the $\mathrm{T}_{0}$ (control), the maximum in the number of shoots per bush was recorded with $\mathrm{T}_{10}$ (84) was found to be superior over the treatment $\mathrm{T}_{0}(\mathrm{Control})$ and the maximum plant spread recorded was with the treatment $T_{10}(104.87)$ was found to be superior over the treatment $\mathrm{T}_{0}$ (Control) is shown in the Table 1, these results are in accordance with, Gill et al., (2015), Singh et al.,(2018) in Phalsa, Kumar et al., (2017) in Strawberry and Rasha El-Said et al.,(2019) in Grapes, whereas yield and quality attributes such as days taken from pruning to flowering is found to non significant may be due to delay in the pruning which was done January. The maximum number of flowering nodes per bush was recorded with the treatment $T_{10}$ (23.33) was found to be superior over the treatment Control $\mathrm{T}_{0}(8.33)$, the maximum average number of fruit was recorded with the treatment $\mathrm{T}_{10}$ (4580.33) was found to be superior over Control $\mathrm{T}_{0}$ (999.67), the maximum fruit yield $\mathrm{kg}$ per bush was recorded with treatment $T_{10}$ (3.95) which was found to be superior over the treatment Control $\mathrm{T}_{0}$ (1.19), the maximum T.S.S $\left({ }^{0}\right.$ Brix) was recorded with the treatment $\mathrm{T}_{10}$ (24) was found to be superior over the treatment control $\mathrm{T}_{0}(18)$, and the minimum Titratable acidity was recorded with the treatment $\mathrm{T}_{10}$ (1.98) and maximum recorded with the treatment $T_{0}(2.96)$ which are shown in the table 2. These present findings are in accordance with Verma et al., (2014), Singh et al., (2018), Sutariya et al., (2018) in Phalsa,
Kumar et al., (2017) in strawberry, Jouse et al.,(2019) in Habanero chilli and Hak El- Said et al., (2019) in garpes, Zagzog et al., (2017) in mango. Thus based on the findings from above mentioned results, it is concluded that the combined application of Nitrogen, Potassium and Zinc nanofertilizer resulted in better growth, higher yield and quality of the fruits in Phalsa through the treatment $\mathrm{T}_{10}(\mathrm{~N}$ $100 \mathrm{~g}+\mathrm{K} 40 \mathrm{~g}+\mathrm{Zn} 0.4 \%$ ).

\section{References}

Albrecht, M.A. Evans, and Rasto, C.L (2006) .Green chemistry and the health implications of Nanoparticles. Green chem.8(4) 17-32.

Al-juthery and Saadoun (2018) Effect of foliar applications of some micronutrient nanofertilizer on growth and yield of Jerusalem artichoke. Iraqi Journal of agricultural science, 49(4).

Gill Bikrajmit Singh, Khehra Savreet, Kaur Guroinder (2015) Effect of Inorganic fertilizers on the plant growth and fruit quality in Phalsa (Grewia asiatica D.C.) Advance Research Journal for Crop Improvement 6(2):100-104.

JosueJosue, Guillermo Nino-Medina, Emilio Olivares-Saenz, Ricardo H. LiraSaldivar, Enrique Diaz Barriga-Castro, Rigoberto VazQuez-Alvarado, PabloA. Rodriguez-Salinas and Francisco Zavala-Gracia (2019) foliar application of Zinc oxide Nanoparticle and zinc sulfate boosts the content of bioactive compounds in Habanero peppers. MDPI Plants 8(254):1-20.

Rasha El-Said Abd El-Hak El-Said, Saeed Abd El-Aty El- Shazly, Ahmed Abd ElFattah Mahmoud El-Gazzar, Essam Abd El-Azeez Shaaban and Mohamed Maher Saad Saleh, (2019) Efficiency of Nano-Zinc foliar spray on Growth, yield and fruit quality of Flame seedless Grape. Journal of applied sciences 
19:612-617.

Reynolds, GH. (2002) Forward to the future nanotechnology and regulatory policy. Pac. Res. Inst., 24:1-23.

Singh Ashutosh Kumar, Yadav Al and Kumar Anil (2018) Effect of pruning intensity, foliar feeding of P.G.R and micro nutrients on vegetative growth of Phalsa (Grewia subinaequalis) Journal of Pharmacognosy and Phytochemistry 2:35-37.

Singh Shashank and Singh H.K (2017) Influence of pruning and foliar application of nutrients on Growth, yield and sugar content of Phalsa (Grewia subinaequalis D.C.) International journal of current microbiology and applied sciences 6(3):2221-2227.

Sutariya N.K, Patel M.J, Patel H.A, and Vasara RP (2018) Effect of integrated nutrient management in bio chemical parameters of Phalsa (Grewia Subinaequalis L) cv. Local, Journal of Pharmacognosy and Phytochemistry 7(5):408-411.

Sutariya NK, Patel MJ, Patel HA and Vasara
RP (2018) Effect of integrated nutrient management on bio chemical parameters of Phalsa (Grewia Subinaequalis) cv. Local. Journal of Pharmacognosy and Phytochemistry 7(5):408-411.

Tripathi Prakash (2009) Phalsa (Grewia subinaequalis) cultivation,

Verma, R.S, Singh, H.K, Verma S.S (2014) Effect of integrated nutrient management on the plant growth, fruit yield and quality of Phalsa (Grewia subinaequalis). Asian journal of Horticulture 9(1) 48-52.

Verma, R.S, Singh, H.K, Verma S.S. (2014) Effect of integrated nutrient management: on the plant growth, fruit yield and quality of Phalsa (Grewia Subinaequalis D.C.) Asian journal of Horticulture 9(1): 48-52.

Zagzog Osama Ahmed, Gad Mohamed Momtaz, Hafez Naglaa Kamal (2017) Effect of nano-chitosan on vegetative Growth, Fruiting and Resistance of malformation of Mango. Trends in Horticulture Research, 7:11-18.

\section{How to cite this article:}

Bini Marina James and Prasad, V. M. 2020. Effect of Nitrogen, Potassium and Zinc Nanofertilizer on Growth, Yield and Quality of Phalsa (Grewia subinaequalis). Int.J.Curr.Microbiol.App.Sci. 9(10): 2528-2533. doi: https://doi.org/10.20546/ijcmas.2020.910.304 